\title{
Jay Sigmund and Grant Wood
}

The names of Grant Wood and Jay Sigmund go together like bread and butter, like bacon and eggs, or like the poet William Cullen Bryant and the painter Thomas Cole. These two Iowa artists may be viewed in an artistic linkage that is perhaps a unique example of symbiosis, the living together of two distinct organisms in an association that is mutually beneficial. If poetry is painting a picture with words, and art is in a sense writing a poem with paints, then the symbiotic nature of Grant Wood's paintings and Jay Sigmund's poems comes about quite naturally. Both artists were born in east central Iowa near the Wapsipinicon River. They both knew and loved this rural area of the state and used their particular talents to immortalize its beauty and realism. They were good friends, neighboring back and forth between Waubeek, Stone City, and 5 Turner Alley, Cedar Rapids.

Jay Sigmund was born on a farm south of Waubeek, Iowa, in 1885 . Before his death in a hunting accident in 1937, he had published more than 1,200 poems, 125 short stories, and 25 one-act plays, some of the latter coauthored with Betty Smith of A Tree Grows in Brooklyn fame.

Like the poet Wallace Stevens, he became vice-president of an insurance company. His work days were spent largely in the city of Cedar Rapids, but he never lost his love of nature, spending his weekends and summers roaming the hills near Waubeek and the banks of the Wapsipinicon River. As Clyde Tull of Cornell College once observed, "Mr. Sigmund's work is characterized by a fine sincerity and a sympathetic understanding of the small town and country folks whom he portrays so vividly in his stories and poems, and by a quiet mastery of technique that attracts little attention to itself but which gives pleasure to the discriminating reader." His work was appreciated by such readers as the Irish poet "A.E." (George Russell), by Robinson Jeffers, George Sterling, Carl Sandburg, H. L. Mencken, and Edmund Blunden. Count Ilia Tolstoi, son of the great

\footnotetext{
'Remarks at the dedication of Jay G. Sigmund Park, Waubeek, lowa, September 27, 1964. See also Professor Tull's similar remarks in the special Jay Sigmund number of the Husk vol. 8, no. 2 (March 1929): 8.
} 
Tolstoi, hailed Mr. Sigmund as an "American Chekhov."2 As a patron of the arts in Cedar Rapids, he gave aid and encouragement to many, including the young Paul Engle, when Paul was his paper boy, and of course Grant Wood.

Grant and Jay were both regionalists. Jay Sigmund, who always was an advocate of regionalism, encouraged Grant Wood in this direction. It was in 1928 at Waubeek that Jay convinced Grant that he should quit running to France, that he should stay home and paint the lowa scene that he knew best. That is what he did after his trip to Munich, Germany, in 1928 to supervise the stained-glass window which is now in the Veterans Memorial Building in Cedar Rapids. That was Wood's last trip abroad. Thereafter he stayed home and painted Iowa-Woman with Plants, Stone City, American Gothic, Daughters of Revolution among others - and then later his notable lithographs of the Iowa scene.

Let us consider here, in a brief comparison of four poems and paintings, the symbolic mirrorings of two different art forms, the paintings of Grant Wood and the poetry of Jay Sigmund.

The painting entitled Stone City, presently in the Joslyn Art Museum in Omaha, is an excellent example of Grant Wood's composition. He created a symmetry of motion by relocating the actual hills and trees and roads. Paul Engle said of Grant Wood, "He did not move mountains. There are no mountains in lowa, but he did move hills to give a better artistic effect."

Here is Jay Sigmund's complementary poem entitled "Stone City."

\section{Stone City, Iowa}

The world had folded up its crust

In giant wrinkles and the rain

Falls gently on these fields of dust

As though to cool Earth's pain.

Mighty the travail of the land

When flames within the sphere subside-

When the Master Artist rests His hand

And views his work with pride.

\footnotetext{
${ }^{2}$ Letters from these and many other critics are among the four feet of Sigmund Papers now in the lowa Authors Collection at The University of Iowa Libraries. In addition to correspondence, this collection includes manuscripts of plays, poems, short stories, an unpublished novel, as well as scrapbooks and newspaper clippings.
} 


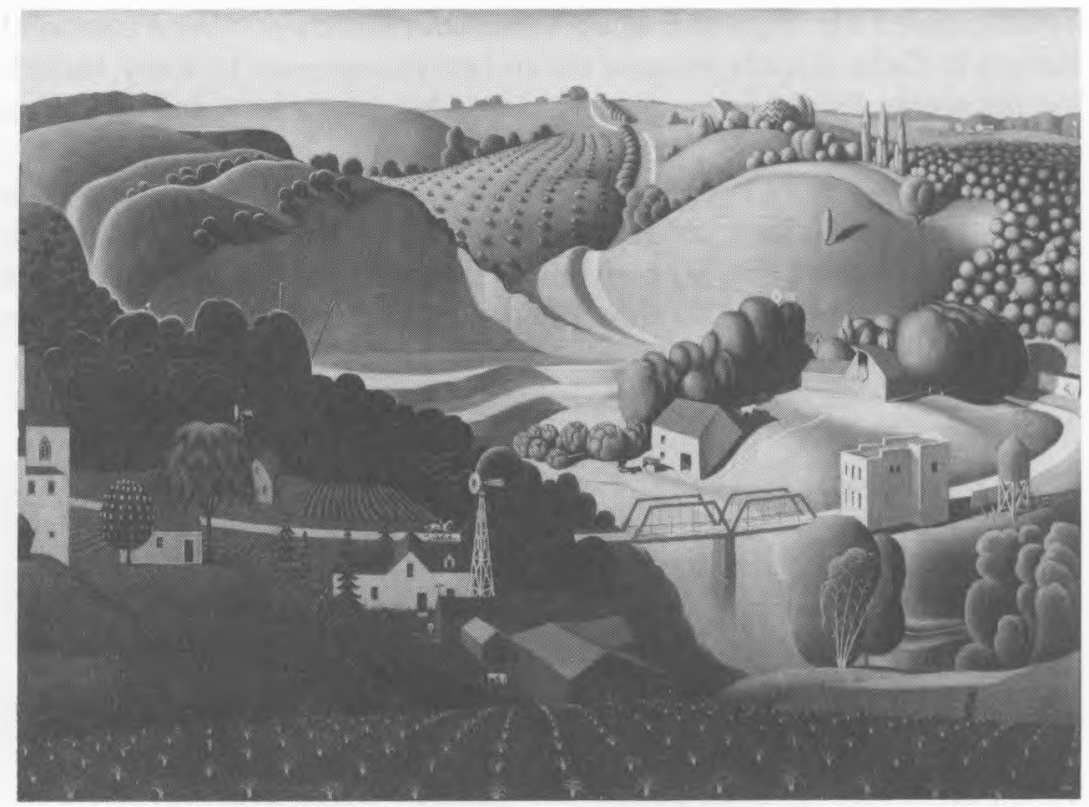

Joslyn Art Museum, Omaha, Nebraska.

The Master's hand was quick and skilled -

The Master's dreams were perfect dreams;

Then from His clouds a river spilled-

The loveliest of streams.

After the river cut the clay

And storms had carved the brooding knolls

The painted red man came this way

And set his teepee poles.

But paler men with stronger wills

Came pressing on and routed him,

Building their towns among these hills

And near the prairie's rim.

And now the hills have given stone

For white men's hearths to rest upon

For the paler men are here alone-

The river still threads on.

The wrinkles of the earth are planed

To smoothness by the storms and frost

But the Master's vision is sustained-

No dream of His is lost. 
In Jay's poem we can visualize the prehistoric beginnings of the valley of the Wapsipinicon, the sojourn of the Indians, and then the settlement by white people. "The Master's vision is sustained" because today we still see the scene preserved for us by Jay Sigmund and Grant Wood.

Jay Sigmund rarely drove a car. His son Jim drove him most of the time. One Sunday Jim was driving his father, mother, and two sisters from Waubeek to Stone City, where Jay was to be master of ceremonies for one of the Sunday variety shows at Grant Wood's Stone City Art School. Trying to dodge a truck, they were sideswiped by another car.

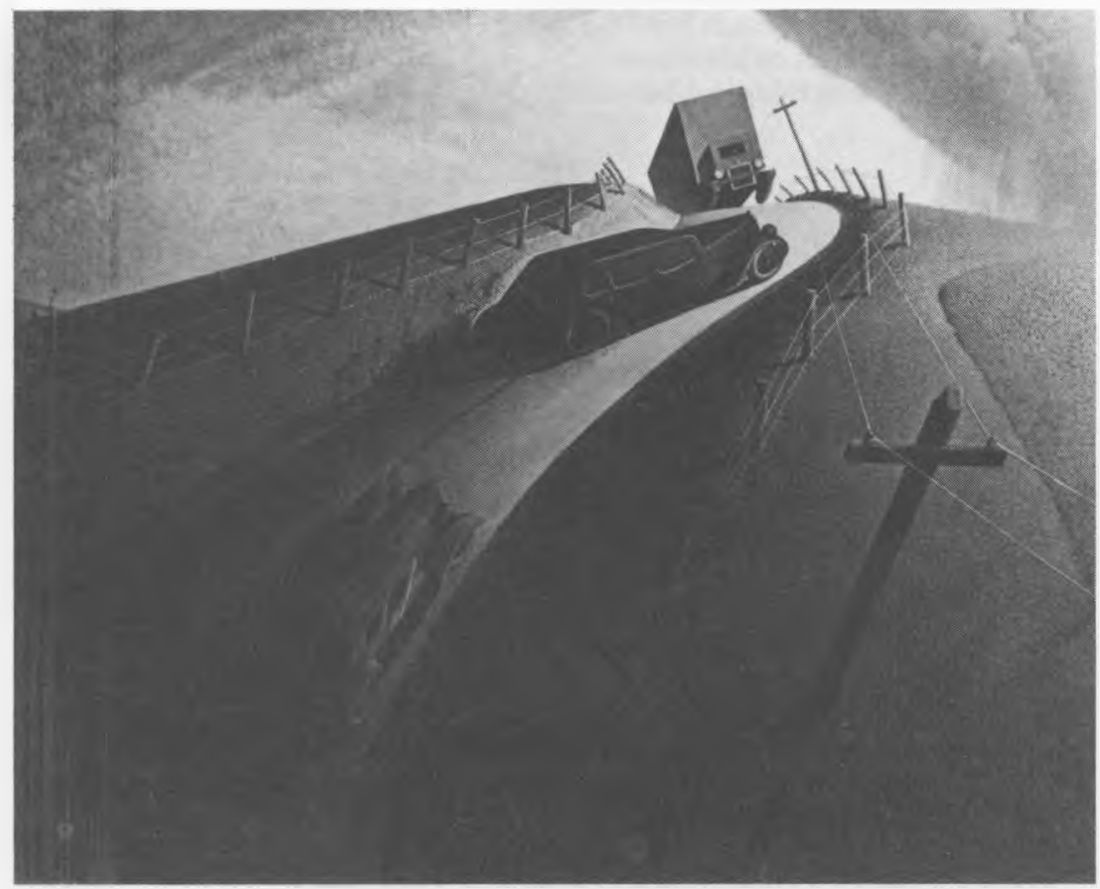

Williams College Museum of Art, Gift of Cole Porter.

The Sigmund car rolled over twice, and Jay's right hand was mangled. In the Anamosa hospital, it was necessary to amputate his index finger, which made writing very difficult for him. He was accustomed to do all his writing in scribbled longhand. Grant rushed out to the scene of the accident and later expressed his memory of the event in picture, as Jay did in poetry: 
Death Rides a Rubber-Shod Horse

A pale grey ribbon of cement

Rippled along the jutting hill

And down its silken course there went

The horse Death rode when out to kill.

A rubber-footed silvered steed,

Needing no impact from a lash;

An eagle's grace; a greyhound's speed-

Two glassy eyes to burn and flash.

Love in the saddle; Death to guide

This devil-horse of steel and brass:

Death riding down the countryside

Supplied with lances made of glass.

Death used to ride a white-maned horse

Before these grey roads lined the sod

But now he travels on his course

Astride a sleek thing, rubber-shod.

Jay died in a hunting accident in October 1937 and his death had a profound effect on Grant Wood. When Wood turned to lithographs in the later years of his life, he drew heavily on Jay's poems for ideas and inspirations. This may be illustrated by another poem-painting combination.

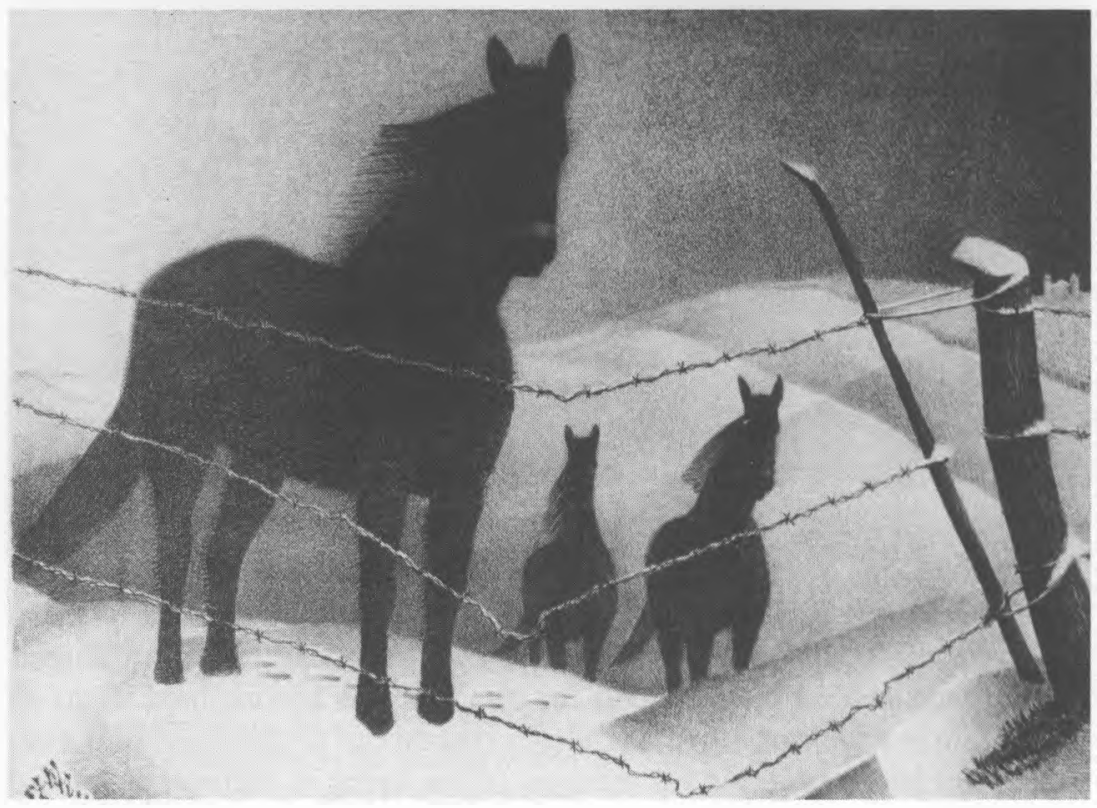

Collection, Davenport Art Gallery, Davenport, lowa. 


\section{Winter Pastoral}

Out on the winter-battered hills

The three gray horses paw:

No harness binds them to the thills;

The snow is thin; the east wind chills -

No manger there; no straw.

The furrows where they dragged a share

And made a bed for seed

Are leveled now and fallow there,

But never a plowman seems to care

Or sense the field-vole's need.

The fisherman brought it in his skiff And moored it to a tree:

I do not wander near the cliff

Nor seek trails where the gales are stiff;

The harsh jay mocks at me.

My winter mood's a smoke-hued one;

I have no heart to sing:

Horses and singer need the sun;

Fishermen wait for carp to run

Against the thaws of Spring.

I saw the plowman by his grate,

Dozing above his pipe;

His rusty plow was near the gate-

His harrow shared a kindred fate-

His crop was stored and ripe.

And in the rutted pasture clay

The woodchuck's den is sealed:

The black crows scold and flap away-

There is no song in such a day,

Nor promise in such a field.

In my master's thesis at The University of Iowa I have matched about 70 paintings and poems that seem to me clearly to complement each other in a symbiotic relationship. People have asked me if Wood and Sigmund painted and wrote together. Who influenced whom? Jay wrote "Winter Pastoral" sometime before 1937, the year he died. Grant painted February in 1941. He likewise painted Death on the Ridgeroad after Jay's death. Jay Sigmund would appear to be the inspiration for Grant Wood. 
Many of Grant Wood's works seem almost to be illustrations for Jay's poems, somewhat in the way Grant illustrated Sinclair Lewis's book Main Street. ${ }^{3}$

In Wood's self-portrait, he clearly dominates the picture, but the details in the background are indeed typical of his expression of regionalism: the almost ever-present windmill, the cornstalks, and the rolling quiltlike pattern of lowa fields.

Such dull fields; corn shocks

\section{Grant Wood}

And drab pasture lands;

"Beauty cannot spring," they said

"From plow-warped hands!"

Farm-towns with grey streets;

Cities, new and raw;

"Loveliness is choked," they cried,

"Where things hold flaw!"

Feet ached from furrows -

The rivers crept by:

Dust wastes of hillside loam

Tortured man's eye.

Stiff prairie cities;

Rambling, crude and fresh:

Nothing here that fancy's net

Dared to enmesh.

But hearts hold soft clay -

And rooted in the knolls

Is seed which the sun plants

To grow rich souls.

Slow years have queer ways

To revel out a skein

But time found a new son

Dreaming on the plain.

Mastering such pigments

As prairie skies spill:

He made autumn sunsets

Blush to his will.

\footnotetext{
${ }^{3}$ Edwin Green of Iowa City, a longtime friend of the artist, identifies the Grant Wood portraits in the Limited Editions Club edition (1937) of Sinclair Lewis's Main Street with the following individuals: The Perfectionist, a portrait of Dorothy Maxon, the wife of Grant's son-in-law; the Sentimental Yearner, Professor Charles Sanders of The University of lowa; The Radical, Grant's son-in-law, Sherman Maxon; the General Practitioner, Dr. A. W. Bennett; the Good Influence, Mollie Green, head waitress of the Jefferson Hotel dining room; the Practical Idealist, librarian Norma Agnes Englert; and The Booster, Frank Luther Mott.
} 


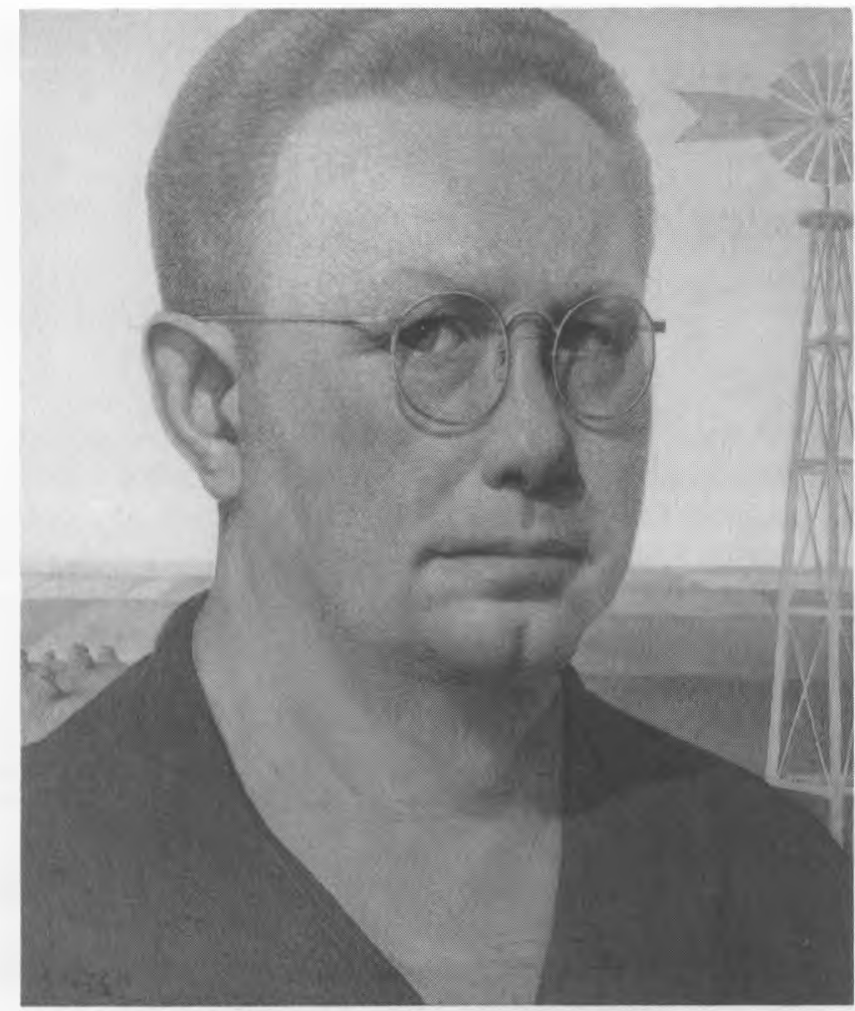

Collection, Davenport Art Gallery, Davenport, lowa.

He captured the wood creek, Brimming full of notes;

He shaped from the lithe birch, Silken swan throats.

When from the loud marts

Brought their silver hint:

Glad that such a genius hand

Gave their world tint.

Men, full of toil-sting, Came to loiter long;

Prayerful that their barns and stacks

Had thus found song.

Jay's poem is a glowing tribute to his friend who possessed a discerning eye and a master's touch which enabled him to portray what other men usually overlooked. Both poet and artist gave to lowans, and to the world, an appreciative revelation of beauty in the ordinary things of life. 